\title{
Differences in Body Composition between Water Polo Players (U18) of the Southeast Europe Top Clubs
}

\author{
Diferencias en la Composición Corporal entre los Jugadores de \\ Waterpolo (U18) de los Mejores Clubes del Sudeste de Europa
}

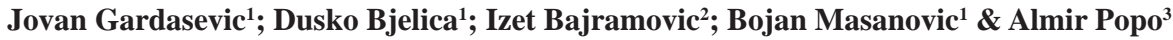

GARDASEVIC, J.; BJELICA, D.; BAJRAMOVIC, I.; MASANOVIC, B. \& POPO, A. Differences in body composition between water polo players (u18) of the southeast europe top clubs. Int. J. Morphol., 39(2):430-435, 2021.

SUMMARY: This research aimed to determine the differences between the junior (U18) water polo players of five Croatian and one Montenegrin clubs in the anthropometric characteristics and body composition. The first sample of the subjects consisted of 14 players of the water polo club Mladost average age 17.57 \pm 0.65 , the second sample consisted of 11 players of the water polo club Sibenik (17.82 \pm 0.65$)$, the third sample consisted of 13 players of the water polo club Primorje (17.23 \pm 1.01 ), the fourth sample consisted of 15 players of the water polo club Mornar (17.13 \pm 0.64$)$, the fifth sample consisted of 13 players of the water polo club Medvescak (17.92 \pm 0.76 ) and the sixth sample consisted of 10 players of the water polo club Jadran Herceg Novi (Montenegro) (17.70 \pm 1.34 ). In the 2010-11 season, these clubs participated in Regional Water Polo League, commonly known as the Regional League or Adriatic League in Southeast Europe. The measurements was conducted in the competition season in the period September-December 2010, at sports centers and swimming pools of water polo clubs that participated in the research. Anthropometric characteristics and body composition were evaluated using a battery of 12 variables: body height, body weight, arm length, arm span, leg length, foot length, chest skinfold, triceps skinfold, back skinfold, abdominal skinfold, upper leg skinfold and body mass index. The standard central and dispersion parameters of all variables were calculated. The significance of the differences between the water polo players of six teams in the variables for assessing anthropometric characteristics and body composition were determined using ANOVA and an LSD Post Hoc test.Based on the central and dispersion parameters, it can be stated that the values of all the variables are highly similar to all of the water polo players of these six clubs. The ANOVA test found that the water polo players of the six international clubs do not have statistically significant differences in the variables for assessing anthropometric characteristics and body composition.

KEY WORDS: Junior water polo players; Anthropometric characteristics; Body mass index of water polo players.

\section{INTRODUCTION}

Water polo is a popular sport worldwide. It is a highly dynamic and fast team game that, with its richness of movement, belongs to the category of polystructural sport games. Water polo is a sport characterized by numerous and various complex and dynamic kinesiological activities, which are then characterized by either cyclical or acyclical movement. It is contact sport characterized by different swimming intensities, duelling, acceleration and deceleration (Gardasevic et al., 2019b). In water polo, top scores can be achieved only under conditions of a wellprogrammed training process. High quality management of the training process depends on knowing the structure of certain anthropological capabilities and water polo players' characteristics, as well as their development.
Various studies have been carried out to establish certain principles and norms for the transformational processes of the anthropological characteristics necessary for water polo, with anthropometric characteristics and body composition among them, as expected. Findings regarding anthropometric characteristics and body composition are of crucial importance for complex sports, such as water polo. The anthropometric space is defined by the longitudinal dimension of the skeleton, the transversal dimensionality of the skeleton, and the mass and volume of the body. The purpose of knowing anthropometric characteristics is to improve skills in many sports (Masanovic et al., 2018). The anthropometric status of toplevel athletes is relatively homogeneous, depending on the

\footnotetext{
${ }^{1}$ Faculty for Sport and Physical Education, University of Montenegro, Niksic, Montenegro.

${ }^{2}$ Faculty of Sport and Physical Education, University of Sarajevo, Sarajevo, Bosnia and Herzegovina.

${ }^{3}$ Faculty of Education, Dzemal Bijedic University of Mostar, Mostar, Bosnia and Herzegovina.
} 
sport, and can be defined as a model of athletic achievement. Research on anthropometric characteristics and body composition among athletes of different sports indicates that athletes of different sports have specific characteristics (Popovic et al., 2013; Bjelica et al., 2019), mostly because absolute size contributes a significant percentage of total variance associated with athletic success (Carvajal et al., 2012). Muscle mass improves performance in activities that require muscular strength and endurance, but also in those that require enviable aerobic ability (Rico-Sanz, 1998).

It is well known that water polo in Montenegro and Croatia has a long tradition and the best results in international competitions. Montenegrins and Croats were the champions of Europe at both clubs and national team's level. Also, young age national teams are always in the European and World top. One of the reasons for their quality is the fact that their junior teams play the international Regional Water Polo League, commonly known as the Regional League or Adriatic League, is a regional water polo league in Southeast Europe. The league was established in 2008 as the "Adriatic Water Polo League" and 2010-11 season consisted of clubs from Croatia, Montenegro and Slovenia (Table I).

Table I. Water polo clubs - participants of the competition season 2010-11 in the Adriatic League.

\begin{tabular}{lc}
\hline Water polo clubs & Country \\
\hline Jug & Croatia \\
Mladost & Croatia \\
Primorje & Croatia \\
Mornar & Croatia \\
Sibenik & Croatia \\
Jadran Split & Croatia \\
Medvescak & Croatia \\
Posk & Croatia \\
Jadran Herceg Novi & Montenegro \\
Primorac & Montenegro \\
Budva & Montenegro \\
Cataro & Montenegro \\
Koper & Slovenia \\
\hline
\end{tabular}

It is clear, these are the best junior water polo players in Croatia and Montenegro, at age 18, because they play in the best water polo clubs in their countries. It is certain that they have had many years of quality training process and many of them to deserve to wear a representative cap. It is well known in all sports and therefore in water polo that only long-term and intensive training is the one that allows to reach the elite representative level and stay in it (Gardasevic et al., 2019b; Gardasevic \& Bjelica, 2020). It became as interesting for researchers to determine the models of anthropometric characteristics of the junior water polo players who play for these six clubs as to determine the differences among them.

This research aimed to determine the anthropometric characteristics and body composition of junior (U18) water polo players, members of five Croatian and one Montenegro clubs who participated at the Adriatic Water Polo League in the 2010-11 season. The variables between these water polo players were compared, and the possible differences between them were determined.

\section{MATERIAL AND METHOD}

In terms of time constraint, the research is of transversal character, and it consists of a one-off measurement of the corresponding anthropometric characteristics and body composition of junior (U18) water polo players.

Sample of subjects. This research consisted of 76 junior (U18) water polo players, members of five Croatian and one Montenegrin clubs. The first sample of the subjects consisted of 14 players of the Croatian Academic Water Polo Club Mladost average age $17.57 \pm 0.65$, the second sample consisted of 11 players of the Croatian Water Polo Club Sibenik of average age 17.82 \pm 0.65 , the third sample consisted of 13 players of the Croatian Water Polo Club Primorje average age $17.23 \pm 1.01$, the fourth sample consisted of 15 players of the Croatian Water Polo Club Mornar average age $17.13 \pm 0.64$, the fifth sample consisted of 13 players of the Croatian Water Polo Club Medvescak average age $17.92 \pm 0.76$ and the sixth sample consisted of 10 players of the Montenegrin Water Polo Club Jadran Herceg Novi average age17.70 \pm 1.34 .

These clubs participate in Regional Water Polo League, commonly known as the Regional League or Adriatic League in Southeast Europe. The measurements were conducted in the competition season 2010-11 in the period September-December 2010, at sports centers and swimming pools of water polo clubs that participated in the research.

Sample of measures. Anthropometric research has been carried out with respect to the basic rules and principles related to the selection of measuring instruments and measurement techniques, standardized in accordance with the International Biological Program guidelines. For this study, eleven anthropometric measures have been taken: body height, body weight, arm length, arm span, leg length, foot length, chest skinfold, triceps skinfold, back skinfold, abdominal skinfold and upper leg skinfold, and one body 
composition assessment variable: body mass index. Portable anthropometer was used to measure the body height $(\mathrm{cm})$ and leg length to the nearest $0.1 \mathrm{~cm}$, standardized scales was used to measure body weight $(\mathrm{kg})$ to the nearest $0.1 \mathrm{~kg}$, calliper was used to measure all skinfolds ( $\mathrm{mm}$ ), short anthropometer was used to measure arm length and foot length $(\mathrm{cm})$ measuring tape was used to measure arm span $(\mathrm{cm})$. Body mass index (BMI) was calculated as weight $(\mathrm{kg})$ divided by height $(\mathrm{m})$ squared $\left(\mathrm{kg} / \mathrm{m}^{2}\right)$.

Method of data processing. The data obtained through the research were processed using descriptive and comparative statistical procedures. For each variable, central and dispersion parameters have been processed. The significance of the differences between the junior water polo players, members of five Croatian and one Montenegrin clubs in the anthropometric characteristics and variable for assessing body composition were determined by ANOVA and LSD Post Hoc tests, with statistical significance of $\mathrm{p}<0.05$.

\section{RESULTS}

The variables for assessing anthropometric characteristics and body composition of junior players of six water polo clubs from Croatia and Montenegro are shown in Table II.

Based on the central and dispersion parameters of the junior water polo players, members of five Croatian and one Montenegrin clubs (Table II), it can be stated that the values of all the variables are very similar to all junior water polo players of this six clubs. Based on the obtained values of ANOVA (Table II), it can be noted that there were no significant differences in variables for assessing anthropometric characteristics and body composition among the junior water polo players, member these six clubs from Croatia and Montenegro (Fig. 1).

Figure 1 shows that the variables of longitudinal dimensionality (body height, arm length, arm span, leg length and foot length) are very similar in all players, members of all clubs. It can be noticed that water polo players of the Montenegrin club Jadran Herceg Novi have the lowest values of subcutaneous fat (chest skinfold, triceps skinfold, back skinfold, abdominal skinfold and upper leg skinfold), which is a disruptive factor for elite sport, although it is not statistically significantly different from other players. However, in the 2010-11 competition season, the water polo players of this club won first place in the Adriatic League, and it is certain that the low value of this parameter had some impact on their success.

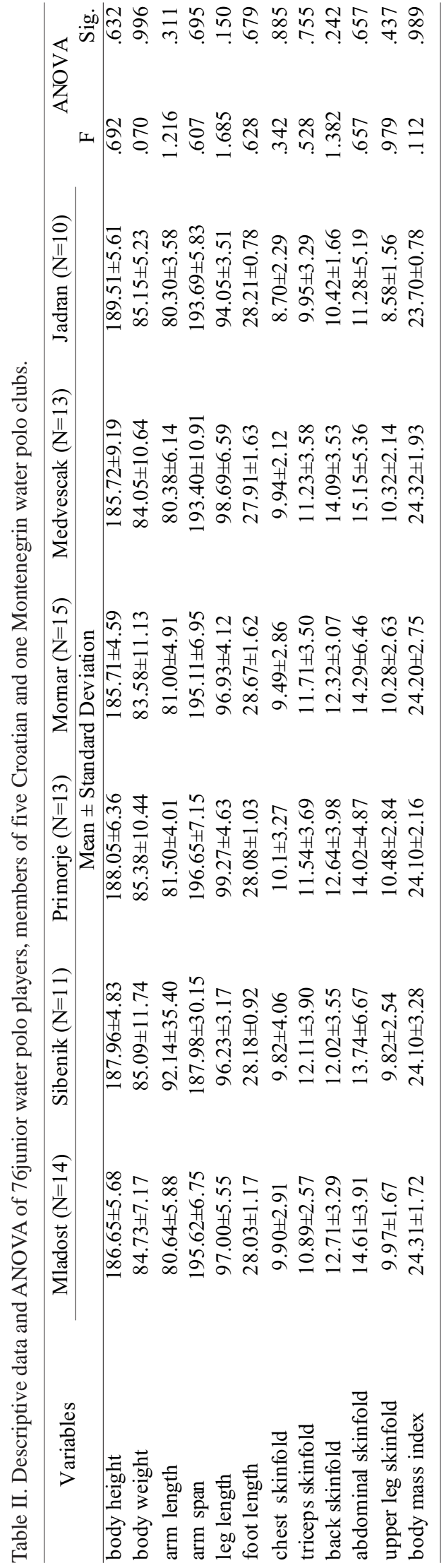



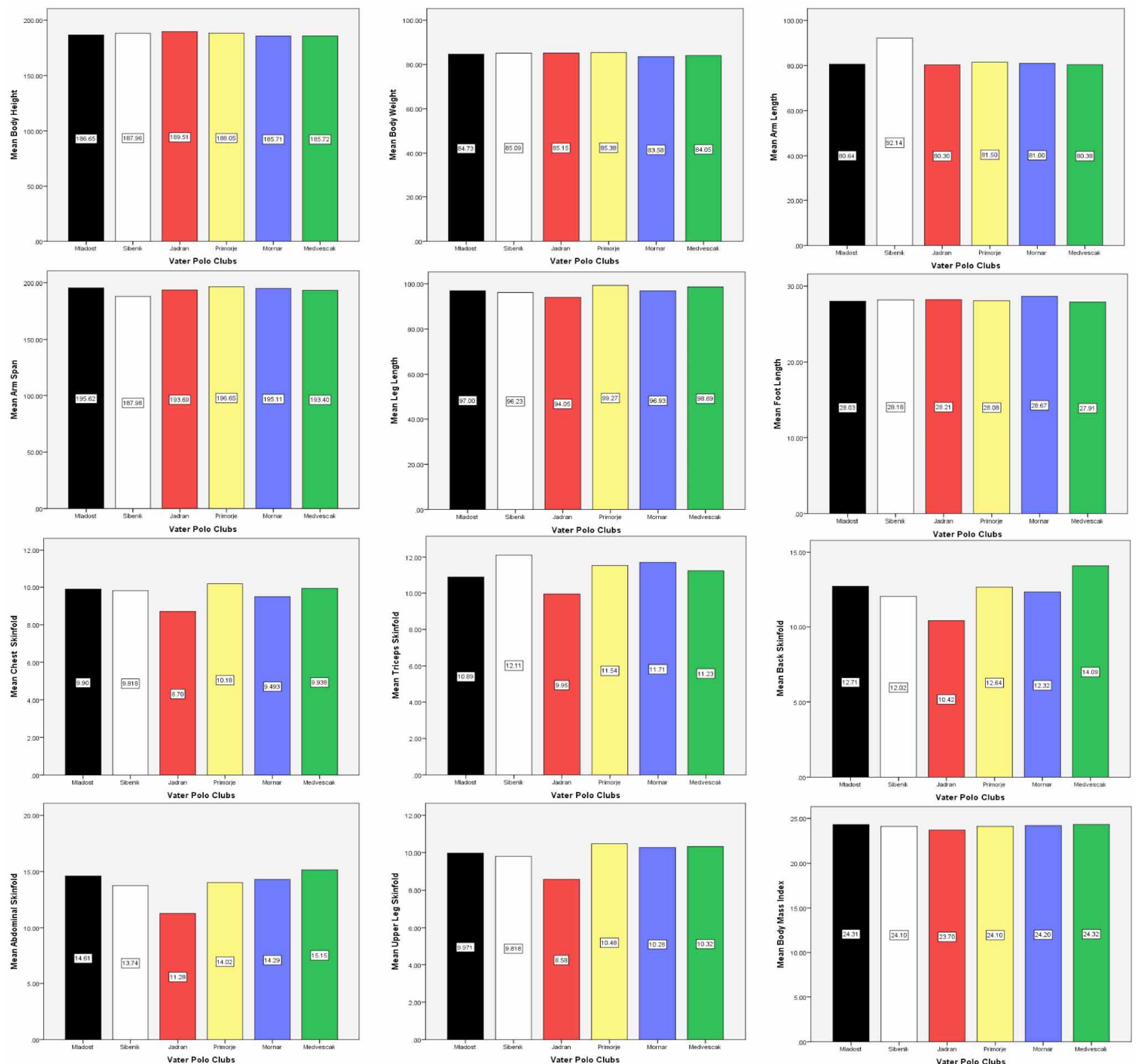

Fig. 1. Differences between junior water polo players, members of five Croatian and one Montenegrin clubs in all variables ( $p>0.05$ ).

\section{DISCUSSION}

This study aimed to determine the difference in the anthropometric characteristics and body composition of the junior (U18) water polo players, members of six Croatian and Montenegrin clubs, who participated in Regional Adriatic Water Polo League, in the competition season 201011. The results were obtained using a battery of 12 tests in the area of anthropometric characteristics and body composition. By examining the basic descriptive statistical parameters, it can be concluded that we have analysed the best selected junior age water polo players from these two countries. Similar results in their research were obtained by Gardasevic et al. (2020). It can be observed that the junior players of six water polo clubs are of the approximately similar mean values of the all variables analysed, which is not surprising because these are the water polo players of the same age, in countries where water polo is popular and in where water polo coaches are highly skilled. These water polo players have years of training experience and spend 
many hours in the pool each week. The ANOVA results showed that the junior players of six Croatian and Montenegrin water polo clubs do not differ significantly in the analysed variables. In all variables there are differences, although, insignificantly for statistics. All of the above mentioned indicates that junior water polo players, members of the best Croatian and Montenegrin clubs have similar anthropometric parameters and body compositions.

Given that the concentration of the best junior water polo players U18 in Southeast Europe at Regional Adriatic Water Polo League, the assumption is that the mean values of the analysed variables of players of six clubs should be the model values for all such clubs in this part of the Europe (Table III).

Table III. Descriptive data of all 76 junior water polo players (U18).

\begin{tabular}{lc}
\hline \multicolumn{1}{c}{ Variables } & Mean \pm Standard Deviation \\
\hline age & $17.54 \pm 0.89$ \\
body height $(\mathrm{cm})$ & $187.11 \pm 6.18$ \\
body w eight $(\mathrm{kg})$ & $84.61 \pm 9.47$ \\
arm length $(\mathrm{cm})$ & $82.43 \pm 14.28$ \\
arm span $(\mathrm{cm})$ & $193.96 \pm 13.30$ \\
leg length $(\mathrm{cm})$ & $97.17 \pm 4.93$ \\
foot length $(\mathrm{cm})$ & $28.19 \pm 1.26$ \\
chest skinfold $(\mathrm{mm})$ & $9.71 \pm 2.91$ \\
triceps skinfold $(\mathrm{mm})$ & $11.27 \pm 3.38$ \\
back skinfold $(\mathrm{mm})$ & $12.48 \pm 3.35$ \\
abdominal skinfold $(\mathrm{mm})$ & $13.98 \pm 5.41$ \\
upper leg skinfold $(\mathrm{mm})$ & $9.97 \pm 2.30$ \\
body mass index $\left(\mathrm{kg} / \mathrm{m}^{2}\right)$ & $24.14 \pm 2.19$ \\
\hline
\end{tabular}

Based on the obtained results in this research, before the end of the competition season 2010-11 in the Regional Adriatic Water Polo League, it could not be assumed which club would achieve a better placement. The Regional Water Polo Championships during each past years showed that they were the quality clubs in which the nuances decide the final standings. All this confirms that these are the best water polo players in the Southeast Europe under the age of 18, many of whom already play for the senior teams.

All junior water polo players of the six Croatian and Montenegrin teams had similar levels of subcutaneous adipose tissue, which is known to be a disruptive factor for athletes (Gardasevic et al., 2019a; Masanovic, 2019). Also, in previous studies of water polo players of this age, subcutaneous adipose tissue has been shown to be a disruptive factor in defence (Milanovic \& Vuleta, 2013). It is well known that a low fat level is desirable for high physical performance in all sports. Although not every body composition characteristic is expected to play a role in optimal performance in professional sport, lower levels of body fat (that are specific to each player) are desirable for optimal performance, as body mass must be moved against gravity (Rienzi et al., 2000; Gil et al., 2007).

In addition, all the water polo players of the six teams had similar values of body height, arm span, arm length, leg length and foot length. Body height, long legs and foot are important for swimming, and long arms and arm span are important for kicks and defence: however, there were no statistically significant differences between the water polo players of the six clubs, which is a confirmation of wellselected players by their coaches. The reason for the different placement in Table of the Regional Adriatic League may be found in the different levels of technical and tactical preparation, and functional and psychological preparation between junior water polo players of the six teams, and we have not analysed it. Experience in playing deciding matches can be the reason for different placement.

The national water polo associations of Croatia and Montenegro, and their clubs should turn to other research studies and check the functional-motoric status, psychological preparation as well as tactical training of their young players, and analyse if there are differences at water polo players that influenced the result at this Regional championship, and whether there is room for improvement. The values obtained in this research can be useful for coaches of these junior teams for making a comparison of their players with others and prepare their work in a way that enables the reduction of adverse parameters, and raise the beneficial ones to a higher level. That will surely make their young water polo players even better and more successful. The results obtained in this research can serve as model parameters for the estimated variables for water polo players (U18) of all clubs in Croatia and Montenegro, and of all junior players in this region (Serbia, Bosnia and Herzegovina, Slovenia...), because the players that have been analysed were the best and the most successful water polo players in their countries, and participants in the Regional Adriatic Water Polo League.

GARDASEVIC, J.; BJELICA, D.; BAJRAMOVIC, I.; MASANOVIC, B. \& POPO, A. Diferencias en la composición corporal entre los jugadores de waterpolo (U18) de los mejores clubes del sudeste de Europa. Int. J. Morphol., 39(2):430-435, 2021.

RESUMEN: El objetivo de esta investigación fue determinar las diferencias entre los jugadores de waterpolo juvenil (U18) de cinco clubes croatas y uno montenegrino en las características antropométricas y la composición corporal. La primera muestra estuvo conformada por 14 jugadores del club de waterpolo Mladost de una edad promedio $17,57 \pm 0,65$ años, la segunda muestra estu- 
vo conformada por 11 jugadores del club de waterpolo Sibenik $(17,82 \pm 0,65)$, la tercera muestra estuvo conformada por 13 jugadores de waterpolo del club Primorje $(17,23 \pm 1,01)$, la cuarta muestra estuvo formada por 15 jugadores del club de waterpolo Mornar $(17,13 \pm 0,64)$, la quinta muestra estuvo formada por 13 jugadores del club de waterpolo Medvescak $(17,92 \pm 0,76)$ y la sexta muestra consistió en 10 jugadores del club de waterpolo Jadran Herceg Novi (Montenegro) $(17,70 \pm 1,34)$. En la temporada 2010-11, estos clubes participaron en la Liga Regional de Waterpolo, comúnmente conocida como la Liga Regional o Liga Adriática en el sudeste de Europa. Las mediciones se realizaron en la temporada de competencias en el período septiembre-diciembre de 2010, en los polideportivos y piscinas de los clubes de waterpolo que participaron en la investigación. Las características antropométricas y la composición corporal se evaluaron utilizando una batería de 12 variables: altura corporal, peso corporal, longitud del brazo, extensión del brazo, longitud de la pierna, longitud del pie, pliegue del pecho, pliegue del tríceps, pliegue cutáneo de la espalda, pliegue cutáneo abdominal, pliegue cutáneo de la parte superior de la pierna e índice de masa corporal. Se calcularon los parámetros estándar central y de dispersión de todas las variables. Se determinó la significancia de las diferencias entre los jugadores de waterpolo de seis equipos en las variables de evaluación de características antropométricas y composición corporal mediante ANOVA y un test LSD Post Hoc. Con base en los parámetros central y de dispersión, se observó que los valores de todas las variables eran muy similares en todos los jugadores de waterpolo de estos seis clubes. La prueba ANOVA mostró que los jugadores de waterpolo de los seis clubes internacionales no tienen diferencias estadísticamente significativas en las variables para evaluar características antropométricas y composición corporal.

PALABRAS CLAVE: Jugadores de waterpolo junior; Características antropométricas; Índice de masa corporal de los jugadores de waterpolo.

\section{REFERENCES}

Bjelica, D.; Gardasevic, J.; Vasiljevic, I.; Jeleskovic, E. \& Covic, N. Body composition and morphological characteristics of soccer players in Bosnia and Herzegovina. Kinesiol. Slov., 25(1):5-13, 2019.

Carvajal, W.; Betancourt, H.; León, S.; Deturnel, Y.; Martínez, M.; Echevarría, I.; Eugenia Castillo, M. \& Serviat, N. Kinanthropometric profile of Cuban women olympic volleyball champions. MEDICC Rev., 14(2):16-22, 2012.

Gardasevic, J. \& Bjelica, D. Body Composition differences between football players of the three top football clubs. Int. J. Morphol., 38(1):153-8, 2020.

Gardasevic, J.; Akpinar, S.; Popovic, S. \& Bjelica, D. Increased perceptual and motor performance of the arms of elite water polo players. Appl. Bion. Biomech., 2019:6763470, 2019b.

Gardasevic, J.; Bjelica, D. \& Vasiljevic, I. Differences in body composition between water polo players of national teams of Montenegro and Croatia participating in the European U15 Championship 2019. Int. J. Morphol., 38(3):720-5, 2020.

Gardasevic, J.; Bjelica, D. \& Vasiljevic, I. Morphological characteristics and body composition of elite soccer players in Montenegro. Int. J. Morphol., 37(1):284-8, 2019a.
Gil, S. M.; Gil, J.; Ruiz, F.; Irazusta, A. \& Irazusta, J. Physiological and anthropometric characteristics of young football players according to their playing position: relevance for the selection process. J. Strength Cond. Res., 21(2):438-45, 2007.

Masanovic, B. Comparative study of morphological characteristics and body composition between different team players from Serbian junior national league: soccer, handball, basketball and volleyball. Int. J. Morphol., 37(2):612-9, 2019.

Masanovic, B.; Corluka, M. \& Milosevic, Z. Comparative study of anthropometric measurement and body composition of junior soccer and handball players from the Serbian National League. Kinesiol. Slov., 24(3):37-46, 2018.

Milanovic, D. \& Vuleta, D. Association between morphological dimensions of water polo players and play performance indicators. Sport Mont., 11(37-38-39):447-53, 2013.

Popovic, S.; Akpinar, S.; Jaksic, D.; Matic, R. \& Bjelica, D. Comparative study of anthropometric measurement and body composition between elite soccer and basketball players. Int. J. Morphol., 31(2):461-7, 2013.

Rico-Sanz, J. Body composition and nutritional assessments in soccer. Int. J. Sport Nutr., 8:113-23, 1998.

Rienzi, E.; Drust, B.; Reilly, T.; Carter, J. E. L. \& Martin, A. Investigation of anthropometric and work-rate profiles of elite South American international football players. J. Sports Med. Phys. Fit., 40(2):162-9, 2000 .

Corresponding Author: Jovan Gardasevic, PhD University of Montenegro Faculty for Sport and Physical Education Narodne omladine bb 81400 Niksic MONTENEGRO

Email: jovan@ucg.ac.me

Received: 27-09-2020

Accepted: 21-11-2020 